\title{
MODEL PENGUJIAN PERATURAN PERUNDANG-UNDANGAN SATU ATAP MELALUI MAHKAMAH KONSTITUSI
}

\author{
Sholahuddin Al-Fatih \\ Fakultas Hukum, Universitas Muhammadiyah Malang \\ Jl. Raya Tlogomas, No. 246 Dau, Malang \\ Email ; salfatih@umm.ac.id
}

\begin{abstract}
Post-reform of the role of judicial institution is run by two institutions namely the Supreme Court and the Constitutional Court. The duties and authorities of the two institutions are regulated in the Constitution of the Republic of Indonesia 1945 and the act that addresses the three institutions more specifically. Several powers possessed by the Supreme Court and the Constitutional Court, one of them is the authority to judicial review. The Constitutional Court is authorized to review the act on the Constitution of the Republic of Indonesia 1945, while the Supreme Court is authorized to review under the Act on the above legislation.

The unfairness of the regulatory testing function is feared to trigger bureaucratic inefficiency. Based on data released by the Supreme Court Clerk, it was recorded during 2016 that the Supreme Court received 18,514 cases, including the Hak Uji Materi (HUM) subject to legislation under the Act. While the number of cases of judicial review of the Constitutional Court in 2016-2017 amounted to only 332 cases. Therefore, it is necessary to conduct a bureaucratic reform and provide new ideas related to the model of one court of judicial review in Indonesia. So that in this paper will be discussed deeply about problematic of judicial review in Indonesia and the authority of the Constitutional Court to review the act under one roof with SIJURI mechanism.
\end{abstract}

Keywords: Judicial Review, One Roof, Constitutional Court

\begin{abstract}
Abstrak
Pasca reformasi peran kekuasaan kehakiman dijalankan oleh dua institusi yaitu Mahkamah Agung dan Mahkamah Konstitusi. Tugas dan wewenang kedua institusi tersebut diatur dalam UUD NRI Tahun 1945 dan Undang-Undang khusus yang membahas ketiga institusi tersebut dengan lebih spesifik. Dari beberapa wewenang yang dimiliki oleh Mahkamah Agung dan Mahkamah Konstitusi, salah satunya adalah wewenang untuk menguji peraturan perundangan. Mahkamah Konstitusi diberi wewenang untuk menguji Undang-Undang terhadap UUD NRI Tahun 1945, sementara Mahkamah Agung diberi wewenang untuk menguji peraturan perundangan dibawah Undang-Undang.

Ketidakpaduan fungsi pengujian peraturan perundangan tersebut dikhawatirkan dapat memicu inefisiensi birokrasi. Berdasarkan data yang dirilis Kepaniteraan Mahkamah Agung, tercatat selama tahun 2016 Mahkamah Agung menerima 18.514 perkara, termasuk didalamnya perkara Hak Uji Materi (HUM) atas peraturan perundangan di bawah Undang-Undang. Sementara jumlah perkara pengujian Undang-Undang di Mahkamah Konstitusi selama tahun 2016-2017 hanya berjumlah 332 perkara. Oleh karenanya, perlu dilakukan sebuah reformasi birokrasi dan memberikan gagasan baru terkait model pengujian perundangan satu atap di
\end{abstract}


Indonesia. Sehingga dalam tulisan ini akan dibahas mendalam mengenai problematika pengujian peraturan perundangan di Indonesia dan wewenang Mahkamah Konstitusi untuk menguji peraturan perundangan dalam satu atap melalui mekanisme SIJURI.

\section{Kata Kunci : Pengujian Peraturan Perundangan, Satu Atap, Mahkamah Konstitusi}

\section{A. PENDAHULUAN}

Ide dasar mengenai negara hukum telah berkembang sejak lama, bahkan telah diperkenalkan oleh para ilmuwan seperti Plato dan Aristoteles. ${ }^{1}$ Plato berpendapat bahwa negara hukum merupakan negara yang berlandaskan atas hukum dan menjunjung tinggi nilainilai keadilan bagi warganya. Kemudian Aristoteles mempertegas konsep negara hukum tersebut dengan berargumen bahwa tugas utama negara hukum adalah untuk memberikan kesempatan hidup bagi setiap individu hingga mencapai tahap harmoni. ${ }^{2}$ Tentunya, keharmonisan dalam kehidupan berbangsa dan bernegara tidak akan tercapai jika tanpa dilandaskan atas hukum dan keadilan substansial dan prosedural yang berlaku bagi setiap warga negara.

Kesadaran untuk menerapkan keadilan substansial dan prosedural bagi warga negara, diilhami dari luka sejarah dalam Revolusi yang terjadi di beberapa negara, teruama yang terjadi di Eropa. Revolusi Prancis merupakan salah satu pelajaran berharga, bahwa absolutisme di Prancis yang dilakukan oleh Raja Louis XIV dengan mengatakan sabda raja adalah undang-undang yang harus dilaksanakan dengan semboyan negara adalah saya (I'etat c'est moi), telah memunculkan gerakan perlawanan dan pertentangan di kalangan masyarakat. ${ }^{3}$ Raja atau penguasa negara tidak bisa memaksakan kehendaknya dan bertindak otoriter. Dari revolusi Prancis tersebut kita belajar bahwa sifat otoritarianisme hanya akan memantik konflik di tengah masyarakat dan mengaburkan nilai keadilan.

Kondisi yang sama juga pernah terjadi di Indonesia, dimana rezim Orde Baru yang telah berkuasa selama kurang lebih 32 tahun, akhirnya digulingkan oleh rakyat karena telah bertindak secara otoriter. Rakyat yang menginginkan nilai-nilai kedaulatan rakyat dijunjung tinggi, merasa hak-haknya dilanggar oleh penguasa yang berlaku sewenang-wenang. Akhirnya muncullah gerakan-gerakan perlawanan yang kemudian membesar dan mendorong terjadinya revolusi. Atas dasar ini pula, rakyat menginginkan bahwa negara seharusnya berdasarkan atas hukum (rechtstaat), dan bukan berdasar atas kekuasaan (machtstaat) semata. Dengan adanya konsep negara hukum, maka tindakan penguasa dibatasi oleh hukum, dan hukum seharusnya juga menjamin terpenuhi hak-hak masyarakat melalui prinsip kedaulatan rakyat.

Kedaulatan rakyat kemudian dijabarkan menjadi beragam domain kehidupan berbangsa dan bernegara. Salah satunya adalah melalui mekanisme pengujian peraturan perundang-

\footnotetext{
${ }^{1}$ Azhary, Negara Hukum Indonesia, Tinjauan Yuridis Normatif tentang Unsur-unsurnya, (Jakarta: UI Press, 1995), hlm. 23

${ }^{2}$ Abdul Aziz Hakim, Negara Hukum dan Demokrasi di Indonesia. (Yogyakarta: Pustaka Pelajar, 2011), hlm. 12

${ }^{3}$ Suganda Wirananggapati dkk, Sejarah Nasional Indonesia dan Dunia, (Jakarta: PT. Galaxy Puspa Mega, 1992), hlm. 2
} 
undangan. Sebagai negara yang berlandaskan atas hukum dan menjunjung tinggi pemenuhan atas hak bagi warga negaranya, maka Indonesia memberikan kesempaan dan peluang bagi warga negaranya yang merasa hak-haknya tidak diakomodasi dengan baik oleh produk hukum yang berlaku. Mekanisme tersebut seringkali dikenal dengan istilah pengujian peraturan perundang-undangan atau judicial review. Berkaca pada sejarah, konsep mengenai judicial review pertama kali dilakukan di Amerika Serikat dalam kasus Madison vs Marbury di tahun $1803 \mathrm{M}$.

Sebagai negara yang menganut sistem common law, Amerika Serikat menjadikan putusan hakim sebagai corong undang-undang. Saat itu, Hakim Supreme Court (Mahkamah Agung) Amerika Serikat, John Marshall, memberikan putusan atas kasus Madison vs Marbury dengan amar putusan membatalkan aturan yang bertentangan dengan konstitusi. Meskipun Undang-Undang Dasar Amerika Serikat tidak menjelaskan tentang judicial review, namun Marshall yang saat itu menjabat sebagai ketua Supreme Court berpendapat bahwa hakim telah bersungguh-sungguh untuk menjaga konstitusi. Menurut Marshall, konstitusi merupakan supremasi hukum tertinggi (the supreme law of the land) yang harus dijaga, sehingga segala bentuk peraturan perundangan yang bertentangan dengan konstitusi harus dibatalkan dan dianggap tidak berlaku. ${ }^{4}$ Sehingga, sejak saat itulah berlaku konsep judicial review di Amerika Serikat.

Catatan sejarah lain menyebutkan bahwa ide terkait judicial review berkembang saat Hans Kelsen menggagas berdirinya Mahkamah Konstitusi di Austria pada tahun 1919-1920 M. ${ }^{5}$ Sebagaimana kita ketahui bahwa Hans Kelsen juga menggagas konsep tentang negative legislator, yaitu ide untuk membatalkan berlakunya suatu peraturan perundangan melalui putusan pengadilan. Gagasan tersebut mirip dengan ide terkait judicial review. Dari kedua peristiwa bersejarah tersebut, akhirnya konsep judicial review masuk ke Indonesia melalui amandemen UUD NRI Tahun 1945. Amandemen terhadap UUD NRI Tahun 1945 memberikan ruang bagi lahirnya kekuasaan kehakiman yang secara lebih spesifik judicial review menjadi wewenang Mahkamah Agung dan Mahkamah Konstitusi.

Sejak wewenang untuk melakukan judicial review tersebut melekat kepada Mahkamah Agung dan Mahkamah Konstitusi, tercatat sudah ribuan kali dilakukan persidangan judicial review. Berdasarkan data yang dirilis Kepaniteraan Mahkamah Agung, tercatat selama tahun 2016 Mahkamah Agung menerima 18.514 perkara, termasuk didalamnya perkara Hak Uji Materi (HUM) atas peraturan perundangan di bawah Undang-Undang. Sementara jumlah perkara pengujian Undang-Undang di Mahkamah Konstitusi selama tahun 2016-2017 hanya berjumlah 332 perkara. Ketimpangan jumlah permohonan judicial review tersebut sangat jelas berdampak pada beberapa hal, misalnya terkait kualitas putusan, durasi waktu berperkara dan sebagainya. Selain itu juga dapat berdampak pada penegakan konstitusi secara holistik dan integral, karena judicial review dijalankan oleh dua institusi bberbeda yang dikhawatirkan berbeda penafsiran pula. Melihat latar belakang permasalahan tersebut, penulis mencoba

\footnotetext{
${ }^{4}$ Jimly Asshiddiqie, Model-model Pengujian Konstitusional di Berbagai Negara, (Jakarta: Konstitusi Press, 2005), hlm. 31-35

5 Taufiqurrahman Syahuri, Pengkajian Konstitusi tentang Problematika Pengujian Peraturan Perundangundangan, (Jakarta: BPHN KemenkumHAM RI, 2014), hlm, 6
} 
membahas dua hal, yaitu: (1) problematika pengujian peraturan perundangan di Indonesia; dan (2) wewenang Mahkamah Konstitusi untuk menguji peraturan perundangan dalam satu atap.

\section{B. PEMBAHASAN}

\section{PROBLEMATIKA PENGUJIAN PERATURAN PERUNDANGAN DI INDONESIA}

Era reformasi menghadirkan banyak perubahan besar bagi dinamika perkembangan ketatanegaraan Indonesia. Salah satu bagian yang mendapatkan hembusan angin segar era reformasi radalah kekuasaan kehakiman. Hasil amandemen UUD NRI tahun 1945 kemudian memberikan amanat agar dibentuk sebuah lembaga pengawal konstitusi bernama Mahkamah Konstitusi. Amanah tersebut tertuang dalam Pasal 24C UUD NRI tahun 1945 yang kemudian ditegaskan lebih detail dalam Undang-Undang Nomor 24 Tahun 2003 tentang Mahkamah Konstitusi. Sebagai penegak konstitusi, maka wewenang untuk menguji undang-undang terhadap konstiusi atau UUD NRI tahun 1945 adalah jelas merupakan wewenang Mahkamah Konstitusi. Meskipu demikian, sejarah mencatat bhw upaya pengujian undang-undang sebagai mekanisme peradilan konstitusional bukanlah hal baru karena konsep tersebut sebenarnya sudah mulai diperkenalkan oleh Moh Yamin sejak sidang BPUPKI. ${ }^{6}$

Meskipun pada akhirnya ide dari Yamin tersebut ditolak oleh peserta sidang, terutama oleh Soepomo, namun setidaknya sejarah telah mencatat bahwa para founding fathers bangsa ini pernah menggagas konsep tentang peradilan konstitusional untuk menilai kebasahan suatu undang-undang terhadap konstitusi. Hingga akhirnya ide pembentukan lembaga peradilan konstitusional kembali muncul setelah era reformasi bergulir. Selanjutnya pada sidang tahunan MPR tanggal 9 November 2001, diputuskan tentang amandemen ketiga terhadap UUD NRI tahun $1945 .^{7}$ Salah satu hasil dari amandemen ketiga tersebut adalah masuknya pasal 24C tentang Mahkamah Konstitusi. Sebagai lembaga baru, Mahkamah Konstitusi langsung diamanahi beberapa wewenang dan kewajiban penting untuk mengawal konstitusi (the guardian of constitusion), yaitu : (1) menguji undang-undang terhadap Undang-Undang Dasar; (2) memutus sengketa kewenangan lembaga negara yang kewenangannya diberikan oleh Undang-Undang Dasar; (3) memutus pembubaran partai politik; (4) memutus perselisihan hasil pemilihan umum.

Selain empat kewenangan tersebut, Mahkamah Konstitusi juga diamanahi kewajiban, yaitu memberikan putusan atas pendapat DPR mengenai dugaan pelanggaran yang dilakukan oleh Presiden dan/atau Wakil Presiden menurut Undang-Undang Dasar. Dalam perkembangannya kemudian, Mahkamah Knstitusi beberapa kali menerima pelimpahan wewenang dari lembaga kehakiman lainnya, seperti Mahkamah Agung. Tercatat, Mahkamah

\footnotetext{
${ }^{6}$ Jimly Asshiddiqie, Pokok-Pokok Hukum Tata Negara Indonesia Pasca Reformasi, (Jakarta: Bhuana Ilmu Populer, 2007), hlm. 581

Jimly Ashiddiqie, Menuju Negara Hukum yang Demokratis, (Jakarta: PT Bhuana Ilmu Populer Kelompok Gramedia, 2009), hlm. 304-305
} 
Agung pernah memberikan wewenang terkait pengujian sengketa pemilu dan pemilukada kepada Mahkamah Konstitusi. Selain itu, Mahkamah Agung dan Mahkamah Konstitusi seringkali beririsan dalam hal pengujian terhadap keabsahan sebuah peraturan perundangundangan. Sebagaimana diketahui, hanya Mahkamah Agung dan Mahkamah Konstitusi yang mempunyai wewenang untuk melakukan pengujian terhadap peraturan perundangan. Mahkamah Agung berwenang untuk menguji peraturan dibawah undang-undang terhadap undang-undang. sementara Mahkamah Konstitusi berwenang untuk menguji undang-undang terhadap UUD.

Problematika yang kemudian rawan muncul adalah terkait beberapa hal, diantaranya : (1) Menumpuknya permohonan pengujian atas suatu kasus di satu lembaga saja. Mahkamah Agung misalnya, dengan jumlah Hakim Agung sebanyak 44 orang, harus menangani 13.203 perkara untuk periode Januari-Agustus 2017 saja. ${ }^{8}$ Berbeda dengan Mahkamah Konstitusi, meskipun Hakim Konstitusi hanya berjumlah 9 orang, tapi rata-rata perkara yang masuk hanya ratusan. Sementara berdasarkan data yang dirilis Kepaniteraan Mahkamah Agung, tercatat selama tahun 2016 Mahkamah Agung menerima 18.514 perkara, termasuk didalamnya perkara Hak Uji Materi (HUM) atas peraturan perundangan di bawah UndangUndang. Bahkan, dari data di Direktori Putusan, Mahkamah Agung tercatat telah menghasilkan total 2.047 .750 putusan. $^{9}$

Alasan (2) adalah karena respon terhadap suatu permohonan pengujian perundangan dan proses berperkara yang dianggap kurang fair. Pengajuan permohonan judicial review ke Mahkamah Agung mengalami peningkatan dalam kurun waktu 2011-2014. Tercatat secara berurutan, 2011 (50), 2012 (52), 2013 (76) dan 2014 (83) kasus permohonan judicial review. ${ }^{10}$ Jumlah tersebut meningkat di tahun 2015 menjadi 99 kasus permohonan judicial review dengan hanya enam perkara yang dikabulkan. ${ }^{11}$ Melihat tren kenaikan tersebut, menimbulkan kemungkinan bahwa jumlah perkara permohonan judicial review di Mahkamah Agung akan terus naik dari tahun ke tahun. Hal ini tidak terlepas dari luasnya produk hukum yang bisa diajukan judicial review di Mahkamah Agung. Sepanjang kurun waktu 2011-2014 itu saja, berdasarkan laporan tahunan Mahkamah Agung terdapat 22 jenis produk hukum yang dimohonkan judicial review di Mahkamah Agung, meliputi ; peraturan peemrintah, peraturan presiden, peraturan menteri, peraturan MA, peraturan MK, peraturan BI, peraturan KPU, peraturan Komisi Informasi, peraturan lembaga, peraturan daerah, peraturan gubernur, peraturan bupati, peraturan walikota, keputusan presiden, keputusan menteri, keputusan bersama MA dan KY, keputusan KPU, keputusan gubernur, keputusan bupati, keputusan direksi, surat edaran dan keputusan direktorat jenderal. ${ }^{12}$

\footnotetext{
8 Abdullah, Jumlah Hakim Agung Tak Ideal, MA Keluhkan Beban Berat Tangai Perkara, http://www.nasional.kompas.com/read, diakses tanggal 9 oktober 2017.

Nursabah, Asep, Penanganan Perkara di Mahkamah Agung Tahun 2016, http://www.kepaniteraan.mahkamahagung.go.id/index.php, diakses tanggal 9 oktober 2017.

${ }^{10}$ Nur Solikin, M, Transparansi dan Akuntabilitas Perkara di MA, http://www.pshk.or.id/id, diakses tanggal 9 oktober 2017.

11 Dwi Anggono, Bayu, PP Peraturan Paling Banyak Diuji di Mahkamah Agung, http://www.hukumonline.com/berita, diakses tanggal 9 oktober 2017.

12 Ibid.
} 
Luasnya cakupan produk hukum yang bisa dilakukan permohonan judicial review di Mahkamah Agung karena memang aturan tersebut diberikan oleh undang-undang yaitu ketentuan dalam Pasal 8 Undang-Undang Nomor 12 Tahun 2011. Pasal 8 ayat (1) UndangUndang Nomor 12 Tahun 2011 mengatur Jenis Peraturan Perundang-undangan selain yang diatur Pasal 7 ayat (1) mencakup peraturan yang ditetapkan oleh Majelis Permusyawaratan Rakyat, Dewan Perwakilan Rakyat, Dewan Perwakilan Daerah, Mahkamah Agung, Mahkamah Konstitusi, Badan Pemeriksa Keuangan, Komisi Yudisial, Bank Indonesia, Menteri, badan, lembaga, atau komisi yang setingkat yang dibentuk dengan Undang-Undang atau Pemerintah atas perintah Undang-Undang, Dewan Perwakilan Rakyat Daerah Provinsi, Gubernur, Dewan Perwakilan Rakyat Daerah Kabupaten/Kota, Bupati/Walikota, Kepala Desa atau yang setingkat. Maka tidak heran jika beban Mahkamah Agung bisa diprediksi akan semakin meningkat dari tahun ke tahun sebagai dampak dari ketentuan pasal tersebut. Sementara itu, Mahkamah Konstitusi secara spesifik hanya menguji undang-undang terhadap UUD saja.

Problematika tak hanya berkisar pada luasnya cakupan produk hukum yang bisa dilakukan permohonan judicial review di Mahkamah Agung, namun juga bisa dilihat dari proses beracara di Mahkamah Agung yang dianggap kurang fair. Jika berperkara di Mahkamah Konstitusi dilakukan dengan konsep terbuka untuk umum, maka permohonan judicial review di Mahkamah Agung dilakukan secara tertutup. Pemohon hanya diminta untuk mengajukan surat permohonan judicial review melalui surat dan menunggu hasil dengan waktu yang tidak tentu. ${ }^{13}$ Sedangkan proses berperkara di Mahkamah Konstitusi dilakukan secara fair dan terbuka untuk umum, mulai dari pemeriksaan pendahuluan hingga pembacaan amar putusan.

Problematika yang ke (3) adalah terkait penafsiran terhadap keabsahan suatu produk hukum yang tidak bisa dilakukan secara integral. Penafsiran berbeda bisa saja terjadi antara Mahkamah Agung dan Mahkamah Konstitusi, yang mana Mahkamah Agung berwenang melakukan uji materiil, sementara Mahkamah Konstitusi berwenang melakukan uji materiil dan formil terhadap kebenaran dan keabhsahan suatu norma. ${ }^{14}$ Beda kepala beda pula isi pikirannya. Misalnya yang pernah terjadi, mengenai perbedaan penafsiran tentang PK. Dimana melalui Putusan Mahkamah Konstitusi Nomor 34/PUU-XI/2013, Mahkamah Konstitusi membatalkan Pasal 268 ayat (3) KUHAP yang mengatur PK hanya bisa diajukan sekali. Artinya, melalui Putusan tersebut Mahkamah Konstitusi memperbolehkan PK diajukan lebih dari satu kali. Sedangkan Mahkamah Agung menafsirkan PK berbeda melalui SEMA Nomor 7 tahun 2014, yang menjelaskan bahwa PK hanya dilakukan maksimal satu kali. ${ }^{15}$

Hal ini tentu membahayakan masyarakat dan menimbulkan kebingungan. Berbeda halnya jika pengujian terhadap suatu produk hukum dilakukan dalam satu atap, kemungkinan

\footnotetext{
${ }^{13}$ Karsayuda, Rifqinizami, Ahli Pemohon : Ketenuan Proses Uji Materi di MA Multitafsir, diakses dari http://www.mahkamahkonstusi.go.id/berita, diakses tanggal 7 Juni 2018

${ }^{14}$ Kusumasari, Diana, Perbedaan Judicial Review dan Hak Uji Materi, http://www.hukumonline.com/klinik, diakses tanggal 7 Juni 2018

15 Asshidiqie, Jimly, Jangan Persoalkan Puusan MK dan MA Soal Pengajuan PK, http://www.nasional.kompas.com/read, diakses tanggal 7 Juni 2018
} 
tafsir berbeda akan bisa diminimalisir. Dissenting opinion di antara para Hakim Konstitusi memang hal yang mungkin saja terjadi, namun kondisi tersebut dinilai lebih fair jika dibandingkan memisahkan lembaga yang menguji kebasahan suatu produk hukum.

Problematika lain yang mungkin harus segera diatasi adalah terkait memperkuat kedudukan konstitusi. Merujuk pada data pada tahun 2016, dimana Kementerian Dalam Negeri membatalkan 3.143 Perda bermasalah yang dinilai menghambat pertumbuhan ekonomi daerah dan memperpanjang jalur birokrasi, menghambat proses perizinan dan investasi, menghambat kemudahan berusaha dan bertentangan dengan peraturan perundangan-undangan yang lebih tinggi. Bisa jadi, peraturan perundangan dibawah undangundang tersebut juga bertentangan dengan konstitusi. Sayangnya, wewenang Mahkamah Agung hanya bisa menguji peraturan perundangan dibawah undang-undang terhadap undangundang saja. Oleh karenanya, diperlukan sebuah mekanisme atau sistem pengujian peraturan perundangan satu atap yang bisa melakukan pengujian secara integral

\section{WEWENANG MAHKAMAH KONSTITUSI UNTUK MENGUJI PERATURAN PERUNDANGAN DALAM SATU ATAP}

Gagasan untuk memberikan wewenang judicial review satu atap di Mahkamah Konstitusi telah mengemuka sejak lama. Salah satunya terlihat dalam pertemuan para pengajar dan pengamat hukum tata negara di Bukit Tinggi, Sumatera Barat pada 11-13 Mei 2007. ${ }^{16}$ Selain pengujian peraturan perundang-undangan satu atap, forum tersebut juga membahas tentang wewenang menyelesaikan sengketa pemilihan umum (pemilu) dan pemilihan kepala daerah (pilkada) pun sebaiknya diserahkan ke satu lembaga, yakni Mahkamah Konstitusi. Jika dilihat dari perkembangannya, wewenang menyelesaikan sengketa pemilihan umum (pemilu) dan pemilihan kepala daerah (pilkada) kini memang telah dieberikan ke Mahkamah Konstitusi.

Ide pemberlakuan satu atap pengajuan judicial review di Mahkamah Konstitusi merupakan upaya untuk menegaskan bahwa Mahkamah Konstitusi merupakan court of law, dan Mahkamah Agung adalah court of justice, karena judicial review termasuk ke dalam ranah court of law bukan court of justice. ${ }^{17}$ Pengalihan wewenang pengujian peraturan di bawah Undang-Undang dari Mahkamah Agung ke Mahkamah Konstitusi merupakan hal yang wajar. Sebagaimana disebutkan sebelumnya, Mahkamah Agung adalah institusi yang sangat sibuk dengan banyaknya perkara, sehingga pelimpahan kewenangan itu akan meringankan kerja Mahkamah Agung. Sebagaimana dijelaskan sebelumnya, Mahkamah Agung dengan jumlah SDM yang terbatas, harus menangani puluhan ribu kasus tiap tahunnya.

Untuk mewujudkan upaya pengujian peraturan perundangan satu atap melalui Mahkamah Konstitusi, mekanisme dasar yang perlu dilakukan agar pengalihan wewenang pengujian peraturan perundangan di bawah undang-undang menjadi wewenang Mahkamah

\footnotetext{
16 Indrayana, Denny, Wewenang Judicial Review Satu Atap, http://www.hukumonline.com/berita, diakses tanggal 9 oktober 2017.

17 Asshiddiqie, Jimly, MK Siap Ambil Alih Wewenang MA Uji Aturan di Bawah UU, http://www.antaranews.com/print, diakses tanggal 9 oktober 2017.
} 
Konstitusi adalah dengan melakukan perubahan pasal 24A UUD NRI Tahun 1945 yang mengatur tentang Mahkamah Agung. Dalam pasal 24A tersebut dinyatakan, Mahkamah Agung berwenang mengadili pada tingkat kasasi, menguji peraturan perundang-undangan di bawah undang-undang terhadap undang-undang, dan mempunyai wewenang lainnya yang diberikan oleh undang-undang. Jika mekanisme amandemen kelima terhadap UUD NRI Tahun 1945 dirasa cukup sulit untuk dilakukan, maka pemerintah bisa membuat sebuah undang-undang yang menyatakan bahwa penanganan pengujian peraturan perundangundangan di bawah undang-undang dilakukan oleh Mahkamah Konstitusi. Agar skenario tersebut berjalan lancar, dibutuhkan kesepakatan antar para pihak, yaitu antara Mahkamah Konstitusi, Mahkamah Agung, DPR, dan Presiden. ${ }^{18}$

Ketika upaya perubahan terhadap regulasi yuridis tersebut sudah bisa dilakukan, maka teknis dan model judicial review satu atap melalui Mahkamah Konstitusi bisa menggunakan konsep digital. SIJURI atau Sistem Judicial Review Indonesia merupakan sebuah terobosan baru di bidang kekuasaan kehakiman. ${ }^{19}$ Teknis implementasi SIJURI dapat dijabarkan sebagai berikut:

a. Proses bermula dari adanya perkara yang akan diajukan judicial review, dimana proses ini dimohonkan kepada Mahkamah Konstitusi (MK), baik melalui jalur konvensional maupun elektronik, lalu permasalahan ini di tampilkan secara digital melalui SIJURI sebagai sarana publik dalam mengetahui perkembangan dari proses judicial review yang sedang, sebelum, maupun akan berlangsung.

b. Lalu setelah di identifikasi oleh petugas, dipisahkan antara perkara yang syaratnya sudah lengkap dengan .perkara yang syaratnya belum lengkap.

c. Jika sudah lengkap, maka bisa mendapatkan nomor registrasi dari panitera. Nomor tersebut bisa digunakan untuk log in dan memantau perkembangan proses judicial review melalui SIJURI

d. Apabila berkas persyaratan belum lengkap, diberikan waktu 7 hari untuk melengkapi berkas yang dibutuhkan. Jika dalam 7 hari bisa melengkapi, maka sama seperti proses pada poin (c) diatas. Namun jika tidak bisa melengkapi dalam 7 hari, maka pemohon tidakbisa mendapatkan nomor registrasi perkara.

e. SIJURI akan menampilkan record atas pengujian peraturan perundangan sebelumnya, jika perkara judicial review yang diajukan berhubungan dengan perkara yang sebelumnya pernah diajukan juga.

f. SIJURI juga akan mengidentifikasi jenis peraturan perundangan yang diajukan judicial review, sehingga jika peraturan perundangan yang dimohonkan judicial review tidak sesuai dengan wewenang MK, maka sistem akan menolak otomatis

g. Perkembangan proses judicial review bisa dipantau secara online melalui SIJURI dengan cara log in menggunakan nomor registrasi perkara. Hasil putusan juga bisa diunduh melalui SIJURI tersebut.

${ }^{18}$ Ibid.

${ }^{19}$ Ide orisinil dari penulis 
Gambar 1. Proses Judicial Review menggunakan SIJURI

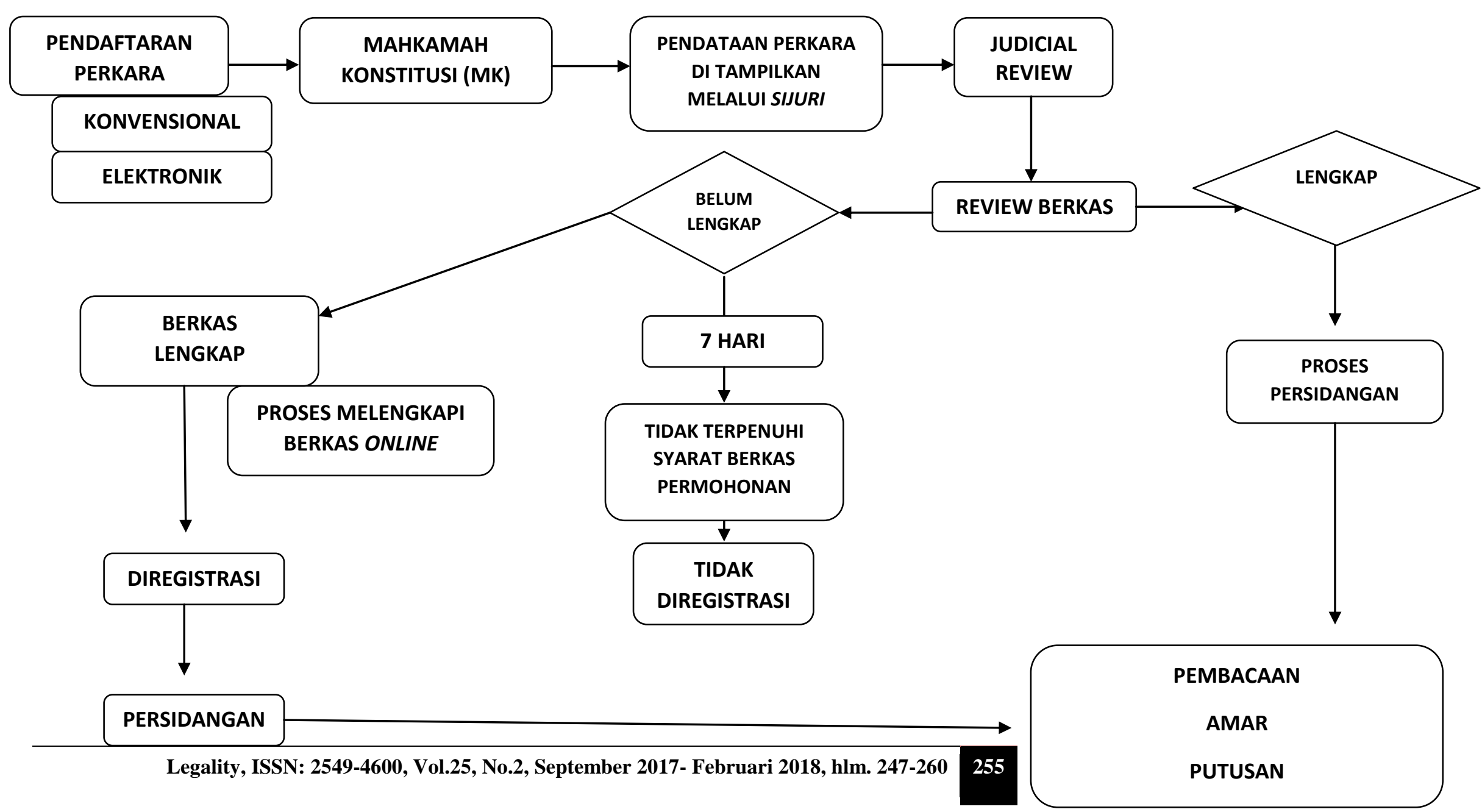


Mekanisme judicial review satu atap bukanlah ide baru. Beberapa negara sudah emnerapkan konsep tersebut lebih dulu. Di Amerika Serikat misalnya, Supreme Court atau Mahkamah Agung dan peradilan yang berada di bawahnya berwenang memutuskan perkara review sebuah produk perundang-undangan. Model Amerika tersebut memperlihatkan bahwa judicial review dapat dilakukan oleh banyak peradilan, namun kesemuanya dalam satu atap di bawah naungan Mahkamah Agung Amerika. Judicial review yang dilakukan oleh lembaga peradilan di bawah MA dapat dibanding ke peradilan di atasnya. Sebagaimana telah disebutkan sebelumnya, sejarah judicial review pertama kali timbul dalam praktik hukum di Amerika Serikat melalui putusan Supreme Court Amerika Serikat dalam perkara Marbury vs Madison tahun 1803. Meskipun ketentuan judicial review tidak tercantum dalam Undang-Undang Dasar Amerika Serikat, Supreme Court Amerika Serikat membuat sebuah putusan yang ditulis John Marshall dan didukung 4 Hakim Agung lainnya yang menyatakan bahwa pengadilan berwenang membatalkan undang-undang yang bertentangan dengan konstitusi.

Meskipun Konstitusi Amerika Serikat tidak menyebutkan secara tekstual mengenai judicial review, namun pada prakteknya di Supreme Court hal tersebut bisa terjadi. Perkara Marbury vs Madison tahun 1803 hanyalah sebuah momentum, dimana sebelum perkara tersebut dijadikan sebuah diskursus mengenai asal lahirnya konsep judicial review, pada tahun 1787 pengadilan di beberapa negara bagian Amerika Serikat telah melakukan upaya membatalkan undang-undang yang bertentangan dengan konstitusi. Dalam perkembangan selanjutnya, Pada tahun 1789 Kongres Amerika Serikat meloloskan Akta Yudikatif, yang memberikan pengadilan federal kekuasaan judicial review atas tindakan pemerintah negara. Kekuatan ini digunakan untuk pertama kalinya oleh Mahkamah Agung Amerika Serikat di Hylton v. Virginia pada tahun 1796.

"The judicial power of the United States shall be vested in one Supreme Court and in such inferior courts that the Congress may from time to time ordain and establish. The judicial power shall extend to all cases, in law and equity, arising under the Constitution, the laws of the United States and Treaties."

"Kekuasaan kehakiman Amerika Serikat akan diberikan untuk satu lembaga kehakiman saja, yaitu Mahkamah Agung dan di pengadilan yang berada setingkat dibawahnya sehingga Kongres dari waktu ke waktu mampu menjaga dan mempertahankannya. Kekuasaan kehakiman berlaku untuk semua kasus, dalam hukum dan ekuitas, yang timbul dalam konstitusi, hukum Amerika Serikat dan Perjanjian."

Jika kasus Madison vs Marbury begitu melegenda di Amerika Serikat, maka di Austria sejarah mencatat nama Hans Kelsen sebagai pelopor lahirnya konsep judicial review sekaligus penggagas Mahkamah Konstitusi Austria. Konstitusi Austria berwenang memeriksa perkara judicial review secara satu atap. Mahkamah Konstitusi Austria berwenang menguji undang-undnag negara bagian atau negara federal. Mahkamah Konstitusi Austria berwenang pula untuk menguji keserasian konstitusi negara bagian dan 
negara federal. Permintaan judicial review bisa dilakukan oleh Mahkamah Agung, Pengadilan Tata Usaha Negara, Pemerintah Negara Bagian atau Federal serta sepertiga dari anggota Nationlarata atau parlemen. ${ }^{20}$

Selain Amerika Serikat dan Austria, negara-negara yang telah menerapkan konsep judicial review satu atap adalah Prancis (constitutional preview dan review), Jerman bahkan Malaysia. Negara-negara yang menerapkan konsep judicial review satu atap mayoritas beranggapan bahwa konsep judicial review satu atap lebih efektif dan efisisen. Selain itu juga, dalam konteks ke-Indonesia-an, konsep judicial review satu atap dapat memperkuat kedudukan, peran dan fungsi Mahkamah Konstitusi. Penafsiran secara integral dan holsitik terhadap konstitusi dapat diwujudkan oleh Mahkamah Konstitusi melalui konsep judicial review satu atap tersebut. terlebih, jika dikombinasikan dengan SIJURI sebagai bentuk digitalisasi kekuasaan kehakiman. Tentunya, hal ini akan membuat semakin mudahnya akses publik terhadap proses persidangan sehingga dapat meningkatkan kepercayaan masyarakat terhadap lembaga kehakiman di Indonesia.

\section{PENUTUP}

\section{KESIMPULAN}

Berdasarkan uraian di atas dapat disimpulkan bahwa :

a. Terdapat banyak problematika pengujian peraturan perundangan, seperti : a) Menumpuknya permohonan pengujian atas suatu kasus di satu lembaga saja, dalam hal ini lebih banyak di Mahkamah Agung daripada di Mahkamah Konstiusi; b) Respon terhadap suatu permohonan pengujian perundangan dan proses berperkara di Mahkamah Agung yang dianggap kurang fair dibandingkan di Mahkamah Konstitusi; c) Penafsiran terhadap keabsahan suatu produk hukum yang tidak bisa dilakukan secara integral, sehingga rawan menimbulkan putusan yang multitafsir, seperti dalam Putusan terkait batasan pengajuan PK.

b. Solusi konkritnya adalah dengan menjadikan wewenang pengujian peraturan perundangan dalam satu atap, yaitu melalui Mahkamah Konstitusi. Model pengujian peraturan perundangan satu atap melalui Mahkamah Konstitusi kemudian dilengkapi dengan SIJURI (Sistem Judicial Review Indonesia) yang merupakan bentuk digitalisasi proses judicial review di Indonesia yang user friendly dan open access.

\section{SARAN}

Seyogyanya para stakeholders berani mengambil sikap demi terciptanya iklim kehakiman yang progresif, efektif dan efisien. Kekuasaan kehakiman seharusnya

${ }^{20}$ Disebutkan dalam Pasal 140 ayat (3) konstitusi atau undang-undang dasar Austria 
meninggalkan kesan kaku yang selama ini banyak menghiasi ruang-ruang persidangan. Digitalisasi proses persidangan adalah salah satu solusi konret yang patut dicoba dan diaplikasikan oleh para stakeholders. Untuk lebih memaksimalkan hasil dari gagasan yang ada, perlu rasanya dilakukan riset lanjutan, terutama berkaitan dengan riset mengenai amandemen peraturan perundang-undangan yang berhubungan dengan tugas dan wewenang Mahkamah Konstitusi dan Mahkamah Agung.

\section{DAFTAR PUSTAKA}

\section{Buku}

Asshiddiqie, Jimly, 2009, Menuju Negara Hukum yang Demokratis, Jakarta: PT Bhuana Ilmu Populer Kelompok Gramedia.

2007, Pokok-Pokok Hukum Tata Negara Indonesia Pasca Reformasi, Jakarta: Bhuana Ilmu Populer Kelompok Gramedia.

2005. Model-model Pengujian Konstitusional di Berbagai Negara, Jakarta: Konstitusi Press.

Azhary, 1995, Negara Hukum Indonesia, Tinjauan Yuridis Normatif tentang Unsurunsurnya, Jakarta: UI Press.

Aziz Hakim, Abdul, 2011, Negara Hukum dan Demokrasi di Indonesia, Yogyakarta: Pustaka Pelajar

Hatta, Mohammad, 1977, Menuju Negara Hukum, Jakarta: Idayu Press

Mahfud MD, Moh., 1999, Hukum dan Pilar-Pilar Demokrasi, Yogyakarta: Gama Media.

Soedarsono, 2006, Mahkamah Konstitusi sebagai Pengawal Demokrasi, Jakarta: Sekjen dan Kepaniteraan MKRI,

Syahuri, Taufiqurrahman, 2014, Pengkajian Konstitusi tentang Problematika Pengujian Peraturan Perundang-undangan, Jakarta: BPHN KemenkumHAM RI.

Wirananggapati, Suganda, dkk, 1992, Sejarah Nasional Indonesia dan Dunia, Jakarta: PT. Galaxy Puspa Mega.

\section{Internet}

Abdullah, Jumlah Hakim Agung Tak Ideal, MA Keluhkan Beban Berat Tangai Perkara, http://www.nasional.kompas.com/read, diakses tanggal 9 oktober 2017.

Asshidiqie, Jimly, Jangan Persoalkan Puusan MK dan MA Soal Pengajuan PK, http://www.nasional.kompas.com/read, diakses tanggal 7 Juni 2018 
Asshiddiqie, Jimly, MK Siap Ambil Alih Wewenang MA Uji Aturan di Bawah UU, http://www.antaranews.com/print, diakses tanggal 9 oktober 2017.

Dwi Anggono, Bayu, PP Peraturan Paling Banyak Diuji di Mahkamah Agung, http://www.hukumonline.com/berita, diakses tanggal 9 oktober 2017.

Hidayat, Arief, MK : Mekanisme Pengujian Peraturan Perundang-Undangan di MA Konstitusional, www.mahkamahkonstitusi.go.id/index.php, diakses tanggal 9 oktober 2017.

Indrayana, Denny, Wewenang Judicial Review Satu Atap, http://www.hukumonline.com/berita, diakses tanggal 9 oktober 2017.

Karsayuda, Rifqinizami, Ahli Pemohon : Ketenuan Proses Uji Materi di MA Multitafsir, diakses dari http://www.mahkamahkonstusi.go.id/berita, diakses tanggal 7 Juni 2018

Kusumasari, Diana, Perbedaan Judicial Review dan Hak Uji Materi, http://www.hukumonline.com/klinik, diakses tanggal 7 Juni 2018

Nur Solikin, M, Transparansi dan Akuntabilitas Perkara di MA, http://www.pshk.or.id/id, diakses tanggal 9 oktober 2017.

Nursabah, Asep, Penanganan Perkara di Mahkamah Agung Tahun 2016, http://www.kepaniteraan.mahkamahagung.go.id/index.php, diakses tanggal 9 oktober 2017.

\section{Jurnal dan Makalah}

Asshiddiqie, Jimly, 2008, Konstitusi dan Hak Asasi Manusia, Makalah disajikan dalam peringatan 10 Tahun KontraS, Jakarta, 26 Maret 2008.

Pusako FH Unand, 2010, Perkembangan Pengujian Peraturan Perundang-undangan di Mahkamah Konstitusi, Jurnal Konstitusi, Volume 7 Nomor 6, Desember 2010, Jakarta: Mahkamah Konstitusi.

\section{Peraturan Perundang-undangan}

Undang-Undang Dasar Negara Republik Indonesia Tahun 1945

Undang-Undang Nomor 12 Tahun 2011 tentang Pembentukan Peraturan Perundangundangan

Undang-Undang Nomor 8 Tahun 2011 tentang Perubahan Atas Undang-Undang Nomor 24 Tahun 2003 tentang Mahkamah Konstitusi 
Undang-Undang Nomor 3 Tahun 2009 tentang Perubahan Kedua Atas Undang-Undang Nomor 14 Tahun 1985 tentang Mahkamah Agung

Kitab Undang-Undang Hukum Acara Pidana

Putusan Mahkamah Konstitusi Nomor 34/PUU-XI/2013

SEMA Nomor 7 Tahun 2014 